\title{
In vitro Sensitivity of Three Alternaria Spp. Vegetable Isolates to Agents of Biological Control and Fungicides
}

\author{
Luis Pérez Moreno*, José Roberto Belmonte Vargas, Luis Roberto Pérez Rodríguez, Rafael Guzmán Mendoza, Diana \\ Sanzón Gómez and Héctor Gordon Núñez Palenius
}

Department of Agronomy, University of Guanajuato, Mexico, North America

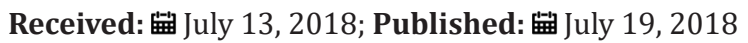

*Corresponding author: Luis Pérez Moreno, Academic Body of Plant Protection (UGTO-CA-81), Department of Agronomy, University of Guanajuato, Mexico, North America, Email: luispm@ugto.mx

\begin{abstract}
The in vitro responses of three Alternaria spp. isolates to 16 biological control agents and eight fungicides were evaluated. A split plot experimental design was used, with a factorial arrangement for each pathogen. Factor A was to fungi isolates and Factor B to control agents. The mean comparisons were by Tukey test. The Alternaria spp. isolates were sensitive to Dicloran, Boscalid, Cyprodinil-Fludioxonil, and Tebuconazole fungicides, because they not allowed any develop of mycelial growth at 264 hours after confrontation. The biological control agents with the best fungistatic effects against to the isolates of Alternaria spp. were four Trichoderma agents, they significantly affected the mycelial growth at 264 hours after confrontation. There were other biological agents such as Bacillus subtillis, B. cereus, B. megaterium (Rhizobac combi), Trichoderma harzianum (Triko root) and Gliocadium virens (Soil gard), but with the lowest or null fungistatic effects.
\end{abstract}

Keywords: Onion; Pepper; Tomato; Bio fungicides; Chemical control

\section{Introduction}

Guanajuato State has an exceptional potential for horticulture; it is in among the first places in the production of 70 species of agricultural importance, some of the most outstanding are onions, garlics (Allium sativum L.), lettuces and potato [1]. However, diseases are one of the most risk factors in the vegetables production. Since few years ago the fungal diseases have caused major economic losses in the production of different vegetable species in Mexico as well as the rest of the world [2]. They have increased their presence in the productive areas of the country, with the Bajio as one of the zones with the highest incidence in that kind of diseases [3]. The most farmers use fungicides as a disease control method, but its use in excess might lead to pathogens resistance, while generating toxic residues in foods and the environment, thus becoming a risk to human health [2]; this has led to a search for new fungicides from other organisms (bio fungicides) [4]. The biological control agents (BCA) of phytopathogens is an efficient and affordable alternative, risk-free in the face of numerous and increasing problems by the excessive agrochemicals use [5]. Based on the problem described above, the aim of this work was to determine the in vitro sensibility to biological control agents and isolated fungicides of two Alternaria species in onion, pepper and tomato plantations. The investigation was carried out in commercial vegetable fields from Abasolo and Penjamo, Guanajuato and in the Plant Pathology Lab of the Life Sciences Division of the Irapuato-Salamanca Campus of the University of Guanajuato.

\section{Obtaining Isolates}

A. porri was isolated from symptomatic onion plants. A. solani was isolated from symptomatic pepper and tomato plants. From each isolate, a part of the tissue with disease symptoms was taken; all samples were disinfected and planted in Potato Dextrose Agar (PDA) for eight days at $20 \pm 2{ }^{\circ} \mathrm{C}$ at room temperature. BCA and fungicides evaluated (Table 1 ) were applied based on commercial recommendations.

\section{In vitro Sensibility Test}

The BCA and fungicides were poured into Petri dishes. When the agar solidified, disks, $1 \mathrm{~cm}$ in diameter were placed in the center of the dish from the periphery of the colonies obtained from each isolation and incubated at $20 \pm 2^{\circ} \mathrm{C}$.

\section{Evaluation of Mycelium Growth}

The colony diameter was measured in two directions - the longest and shortest length - and mycelial growth was obtained as the average of both values at $24,48,72,96,120,144,168,192,216$, 240 , and 264 hours after placing the disk with the fungi on the edge of each Petri dish.

\section{Statistical Analysis}

A split plot experimental design was used, with a factorial arrangement with three repetitions. There was a factorial 
arrangement: factor A was assigned to fungal isolations, which three levels; factor B was assigned to the BCA and fungicides, which 25 levels. This gave a total of 75 treatments. The multiple comparisons of averages were carried out by Tukey's test $(\mathrm{P} \leq 0.05)$.

\section{Results and Discussion}

\section{Alternaria porri and Alternaria solani}

The three isolates of Alternaria were sensitive to four of the eight fungicides (Dicloran, Boscalid, Cyprodinil-Fludioxonil, and Tebuconazole), considering this as those which did not develop a mycelial radial average growth (Mrag), 264 hours after the confrontation (Table 1). Contrasting results were found in the behavior of Alternaria spp. towards the fungicides reported by [6], who showed the presence of insensitivity of the pathogen towards the iprodione. The biological control agents with the greatest fungistatic effects towards Alternaria spp. isolates, that is, those which caused the least Mrag 264 hours after confrontation, were: Trichoderma harzianum (Biotricho H), Trichoderma sp. (Trichoderma), Trichoderma harzianum (Natu control), Trichoderma viride (Esporalis) with 1.15a, 1.16a, 1.26a, and 2.06 c, respectively; in comparison to Bacillus subtillis, $B$. cereus, B. megaterium (Rhizobac combi), Trichoderma harzianum (Triko root) and Gliocadium virens (Soil gard), with $7.21 \mathrm{k}, 7.38 \mathrm{k}$ and $8.42 \mathrm{l}$, respectively, which had the lowest or null fungistatic effects towards the isolates (Table 1). In relation to the response of Alternaria spp. towards the biological control agents evaluated, a wide variability was found, observing that the biological products to which there was a higher sensitivity to in vitro were those formed with Trichoderma spp.; the results obtained in this study coincide with those by [7]; the cause of this greater beneficial effect may be the bio controlling action of Trichoderma spp., in which there have been several forms of action described that regulate the development of phythopathogenic fungi. Among these, the main ones are the competition for space and nutrients, micro parasitism and antibiosis, which have a direct action on the phythopathogenic fungi [8]; it is also known that Trichoderma spp. displays other mechanisms, the bioregulatory action of which is indirect, such as the biochemical defense mechanisms, that consist in the deactivation of enzymes of the phythopathogenic fungi during the infection process [8]; this could explain the high inhibitory percentage of mycelial growth of Alternaria spp.

Table 1: In vitro Mycelial radial average growth (Mrag) of three Alternaria spp. isolates obtained from onion, pepper and tomato, 16 BCA treatments and eight fungicides.

\begin{tabular}{|c|c|c|c|c|c|c|c|}
\hline \multirow[t]{2}{*}{ No. } & \multirow[t]{2}{*}{ Common name } & \multirow[t]{2}{*}{ Tradename } & \multicolumn{5}{|c|}{ Mrag (cm) } \\
\hline & & & 168 Hours & 192 Hours & 216 Hours & 240 Hours & 264 Hours \\
\hline 1 & Dicloran & Botran & $1.00 \mathrm{a}$ & $1.00 \mathrm{a}$ & $1.00 \mathrm{a}$ & $1.00 \mathrm{a}$ & $1.00 \mathrm{a}$ \\
\hline 2 & Benomilo & Blindaje 50 & $2.05 \mathrm{~d}$ & $2.32 \mathrm{~d}$ & $2.58 \mathrm{ef}$ & $2.87 \mathrm{~g}$ & $3.18 \mathrm{e}$ \\
\hline 3 & Boscalid & Cabrio & $1.00 \mathrm{a}$ & $1.00 \mathrm{a}$ & $1.00 \mathrm{a}$ & $1.00 \mathrm{a}$ & $1.00 \mathrm{a}$ \\
\hline 4 & Clorotalonil-Cymoxanil & Strike & $1.34 \mathrm{~b}$ & $1.40 \mathrm{~b}$ & $1.50 \mathrm{c}$ & $1.57 \mathrm{~cd}$ & $1.65 \mathrm{~b}$ \\
\hline 5 & Ciprodinilo-Fludioxonilo & Swish & $1.00 \mathrm{a}$ & $1.00 \mathrm{a}$ & $1.00 \mathrm{a}$ & $1.00 \mathrm{a}$ & $1.00 \mathrm{a}$ \\
\hline 6 & Tebuconazole & Tebucur & $1.00 \mathrm{a}$ & $1.00 \mathrm{a}$ & $1.00 \mathrm{a}$ & $1.00 \mathrm{a}$ & $1.00 \mathrm{a}$ \\
\hline 7 & Iprodione & Rovral & $1.22 \mathrm{ab}$ & $1.27 \mathrm{ab}$ & $1.37 \mathrm{bc}$ & $1.48 \mathrm{bc}$ & $1.62 \mathrm{~b}$ \\
\hline 8 & Clorotalonil & Trevanil & $1.68 \mathrm{c}$ & $1.76 \mathrm{c}$ & $1.82 \mathrm{~d}$ & $1.86 \mathrm{de}$ & $1.95 \mathrm{bc}$ \\
\hline 9 & $\begin{array}{c}\text { Actinomadura viridis } \\
\text { B. subtillis, Streptomyces sp. }\end{array}$ & Baktillis & $3.70 \mathrm{gh}$ & $4.11 \mathrm{hi}$ & $4.50 \mathrm{hi}$ & $5.01 \mathrm{ij}$ & $5.51 \mathrm{~g}$ \\
\hline 10 & T. harzianum & Natucontrol & $1.26 \mathrm{ab}$ & $1.26 \mathrm{ab}$ & $1.26 \mathrm{abc}$ & $1.26 \mathrm{abc}$ & $1.26 \mathrm{a}$ \\
\hline 11 & Streptomyces lydicus & Actinovate & $4.43 \mathrm{j}$ & $4.94 \mathrm{k}$ & $5.46 \mathrm{k}$ & $5.97 \mathrm{~m}$ & $6.44 \mathrm{j}$ \\
\hline 12 & Bacillus sp., Glomus sp. & Soil cure & $3.83 \mathrm{hi}$ & $4.28 \mathrm{ij}$ & $4.76 \mathrm{ij}$ & $5.21 \mathrm{jk}$ & $5.68 \mathrm{gh}$ \\
\hline 13 & control & control & $3.45 \mathrm{fg}$ & $3.90 \mathrm{gh}$ & $4.31 \mathrm{gh}$ & $4.72 \mathrm{hi}$ & $5.15 \mathrm{f}$ \\
\hline 14 & B. subtillis & Bacillus subtillis & $4.02 \mathrm{i}$ & $4.47 \mathrm{j}$ & $4.88 \mathrm{j}$ & $5.45 \mathrm{kl}$ & $6.00 \mathrm{hi}$ \\
\hline 15 & T. harzianum & Biotricho-H & $1.15 \mathrm{ab}$ & $1.15 \mathrm{ab}$ & $1.15 \mathrm{ab}$ & $1.15 \mathrm{a}$ & $1.15 \mathrm{a}$ \\
\hline 16 & Trichoderma sp. & Trichoderma & $1.16 \mathrm{ab}$ & $1.16 \mathrm{ab}$ & $1.16 \mathrm{ab}$ & $1.16 \mathrm{ab}$ & $1.16 \mathrm{a}$ \\
\hline 17 & T. viride & Esporalis & $2.06 \mathrm{~d}$ & $2.06 \mathrm{~d}$ & $2.06 \mathrm{~d}$ & $2.06 \mathrm{e}$ & $2.06 \mathrm{c}$ \\
\hline 18 & B. subtillis & Probacil & 3.62 fgh & $3.95 \mathrm{gh}$ & $4.38 \mathrm{gh}$ & $4.77 \mathrm{hi}$ & $5.16 \mathrm{f}$ \\
\hline 19 & T. harzianum & Triko root & 5.241 & 5.801 & 6.301 & $6.92 n$ & $7.38 \mathrm{k}$ \\
\hline 20 & B. subtillis & Natu bac-s & $3.37 \mathrm{f}$ & $3.78 \mathrm{~g}$ & $4.16 \mathrm{~g}$ & $4.57 \mathrm{~h}$ & $5.01 \mathrm{f}$ \\
\hline 21 & B. subtillis & Serenade max & $2.48 \mathrm{e}$ & $2.65 \mathrm{f}$ & $2.78 \mathrm{f}$ & $2.91 \mathrm{~g}$ & $2.98 \mathrm{e}$ \\
\hline 22 & B. subtillis & Probac bs & $4.41 \mathrm{j}$ & $4.84 \mathrm{k}$ & $5.31 \mathrm{k}$ & $5.76 \mathrm{~lm}$ & $6.21 \mathrm{ij}$ \\
\hline 23 & Micro- organisms & BPG-Plus & $2.38 \mathrm{e}$ & $2.40 \mathrm{ef}$ & $2.41 \mathrm{e}$ & $2.41 \mathrm{f}$ & $2.41 \mathrm{~d}$ \\
\hline 24 & B. subtillis, B. cereus, B. megaterium & Rhizobac combi & $4.93 \mathrm{k}$ & 5.551 & 6.141 & $6.70 \mathrm{n}$ & $7.21 \mathrm{k}$ \\
\hline 25 & Gliocadium virens & Soil gard & $5.66 \mathrm{~m}$ & $6.40 \mathrm{~m}$ & $7.25 \mathrm{~m}$ & 7.98 o & 8.421 \\
\hline
\end{tabular}

Each value represents the average value of three isolates. Data with different letter within columns are significantly different by Tukey test at $\mathrm{P} \leq 0.05$. 


\section{References}

1. Servicio de Información Agroalimentaria y Pesquera (SIAP) (2016) Con información de las Delegaciones de la Secretaria de Agricultura, Ganadería, Desarrollo Rural, Pesca y Alimentación (SAGARPA). Anuario Estadístico de la Producción Agrícola. Resumen Nacional por Producto.

2. Fisher CM, Henk AD, Briggs JC, Brownstein SJ, Madoff CL, et al. (2012) Emerging fungal threats to animal, plant and ecosystem health. Nature 484: 186-194.

3. Montes Belmont BR, Nava Juárez RA, Flores Moctezuma HE, Mundo Ocampo M (2003) Hongos y nematodos en raíces y bulbos de cebolla (Allium cepa L.) en el estado de Morelos, México. Revista Mexicana de Fitopatología 21: 300-303.

4. Angulo Escalante MA, Armenta Reyes E, García Estrada RS, Carrillo Fasio JA, Salazar Villa E, et al. (2009) Extractos de Semilla de Swietenia humilis Zucc, con Actividad Antifúngica en Rhizopus stolonifer (Ehrenb Fr.) Vuill. Revista Mexicana de Fitopatología 27(2): 84-92.

\section{ISSN: 2574-1241}

DOI: 10.26717/BJSTR.2018.07.001449

Luis Pérez Moreno. Biomed J Sci \& Tech Res

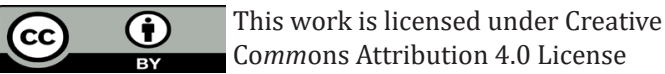

Submission Link: https://biomedres.us/submit-manuscript.php
5. Agrios GN (2005) Plant Pathology ( $5^{\text {th }}$ Edn.), Elservier Academic. University of Florida, USA, pp. 414-426, 453-456, 510-514, 523-526, 546-550.

6. Narro Sánchez J, Quijano Carranza JA, Ramírez Vega M (2006) Control químico de la pudrición del florete (Alternaria spp,) en Brócoli en campo. En: Memorias del XXXIII Congreso Nacional de Fitopatología. Manzanillo, Col, Mexico p. 55.

7. Michel Aceves AC, Otero Sánchez MA, Solano Pascacio LY, Ariza Flores $\mathrm{R}$, et al. (2009) Biocontrol in vitro con Trichoderma spp. de Fusarium subglutinans (Wollenweb y Reinking) Nelson, Toussoun y Marasas y $F$. oxysporum Schlecht., agentes causales de la "escoba de bruja" del mango (Mangifera indica L). Revista Mexicana de Fitopatología 27(1): 18-26.

8. Infante D, Martínez B, González N, Reyes Y (2009) Mecanismos de acción de Trichoderma frente a hongos fitopatógenos. Revista protección vegetal 24(1): 14-21.

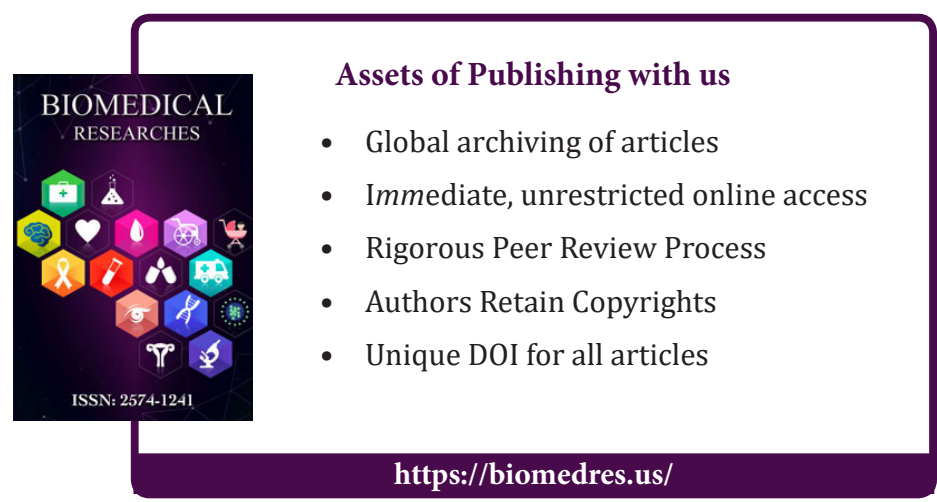

